\title{
The Emergence of New States in International Law: The Insights from Complexity Theory
}

\author{
Steven Wheatley*
}

\begin{abstract}
Doctrinal controversies and the disputed international status of Kosovo and Palestine suggest that it is difficult for us international lawyers to know with any certainty when a new State has emerged in the international community. The contention here is that we should look to systems theory thinking-specifically complexity theory-to make sense of the law on statehood. Systems theory directs us to conceptualize the State in terms of patterns of communications adopted by law and politics actors and institutions and applied to subjects. Complexity tells us that these patterns develop without any central controller or guiding hand and that they exist only as a consequence of the framing of law and politics communications by a third party observer. The argument developed in this article is that these insights can provide the intellectual "scaffold" around which we can build our model of the international law on statehood.
\end{abstract}

\section{Introduction}

1. This article considers what should be a straightforward question: how do we (international lawyers) know when a new State has emerged? The existence of a number of "unrecognized States", such as Somaliland and the Turkish Republic of Northern Cyprus, and the divided practice of recognition in relation to Kosovo and Palestine, along with doctrinal controversies as to the influence of the right of peoples to self-determination and other jus cogens norms on the law on statehood all suggest that, at present, it is difficult for us

* Professor of International Law, Lancaster University, Centre for International Law and Human Rights, UK. Email: s.wheatley@lancaster.ac.uk. Previous versions of this paper were presented at the Department of Law, London School of Economics (November 2013); and a Conference on "Sovereignty in the 21st Century" (British Institute of International and Comparative Law: London, June 2014). Thanks to Jean d'Aspremont, Patrick Capps, and Tom Webb for comments on an earlier draft. Thanks also to the anonymous reviewers for the journal. 
to "know" with any certainty when a new State has emerged. We need then to clarify our thinking on the issue and the proposal here is that we should follow a long tradition in international law scholarship of looking to the methodologies developed by our colleagues in the natural sciences to make sense of the question-specifically that we should look to one variant of systems theory: complexity.

2. Complexity theory is a variant of systems theory thinking. The argument from general systems theory is that we can think of any collection of interacting objects, actors or agents as a "system", and that all systems have certain shared characteristics, whether we are looking at the Solar System or a Criminal Justice System. The objective is to observe, frame and explain the patterned behaviours of objects, actors or agents. Systems theory thinking is now mainstream in international law, ${ }^{1}$ reflecting not only the reality that international law is a "system", ${ }^{2}$ but also a recognition that systems theory as a distinctive methodology might help us solve, or at least make sense of, some of the practical questions that confront the discipline.

3. Complexity theory emerged in the natural sciences to explain the ways in which patterned order could emerge without the need for a "guiding hand" or "central controller", as the structures of certain systems were seen to occur spontaneously - the result of the interactions of the parts of the system as they reacted to new information. Complexity theory has been used, inter alia, to explain the workings of insect colonies and the relationship between the mind (the emergent system) and the brain, which functions through individual neurons (agents) firing and making connections. It has also been relied on by certain social scientists, including international relations scholars. There is now a significant body of scholarly writing that seeks to apply the

1 See, for example, Anthony D'Amato, Groundwork for International Law 108 American JIL (2014), 650, 650 ("International law is a system[:] [an] autopoietic system"). There are points in the analysis, however, where D'Amato uses concepts more readily identified with complexity theory. See also Anthony D'Amato, "Evolution of International Law: Two Thresholds, Maybe a Third", in Papers from the 2009 AAAI Fall Symposium on Complex Adaptive Systems and the Threshold Effect [ aaai.org/ocs/index.php/FSS/FSS09/paper/view/988 (last visited 18 September 2015)], 29 (“[international law] is a complex adaptive system"). See also Andreas Fischer-Lescano and Gunther Teubner, Regime Collisions: The Vain Search for Legal Unity in the Fragmentation of Global Law 25 Michigan JIL (2004), 999.

2 James Crawford, Brownlie's Principles of Public International Law, $8^{\text {th }}$ edition (2012), 15 ("The reality of international law-whatever its theoretical underpinnings - is clearly that of a system of laws"). 
insights from complexity theory to law, ${ }^{3}$ although hitherto complexity ${ }^{4}$ has had limited impact on international law scholarship, ${ }^{5}$ and this is the first work to examine its implications for the international law on statehood and recognition.

4. This article makes two claims: first, that international law is a complex system that emerges from the actions and interactions of States and other international law actors in their international relations; second, (and more importantly for these purposes) that we should model State as the coupling of the complex law and politics systems under a constitution. Drawing on developments in the natural sciences through an application of

3 See, for example, J.B. Ruhl, Law's Complexity: A Primer 24 Georgia State University LR (2007-2008), 885, 897; J.B. Ruhl, Complexity Theory as a Paradigm for the Dynamical Law-And-Society System: A Wake-Up Call For Legal Reductionism and the Modern Administrative State, 45 Duke LJ (19956), 849; Hope M. Babcock, Democracy's Discontent in a Complex World: Cab Avalanches Sandpiles, and Finches Optimize Michael Sandel's Civic Republican Community? 85 Geo. LJ (1996-7), 2085; Gregory Todd Jones, Dynamical Jurisprudence: Law as a Complex System, 24 Georgia State University LR (2008), 873; Julian Webb, Law, Ethics, and Complexity: Complexity Theory \& The Normative Reconstruction of Law, 52 Cleveland State LR (2005), 227; and Thomas E. Webb, Tracing an Outline of Legal Complexity, 27 Ratio Juris (2014), 477.

4 Two dominant themes can be observed in the literature on complexity theory when applied in the social sciences. "Computational complexity" draws on the mathematical theory of complexity developed by computer scientists to develop computational models of complex systems, including law: see, for example, Eric Kades, The Laws Of Complexity And The Complexity Of Laws: The Implications Of Computational Complexity Theory For The Law 49 Rutgers LR (1996-1997), 403. The second approach (and the one developed here) draws primarily on biology and is principally associated with the work of the Santa Fe Institute. There are, of course, other ways that the term can be used: Peter H. Schuck, Legal Complexity: Some Causes, Consequences, and Cures, 42 Duke LJ (1992), 1.

5 Notable exceptions include Dominic McGoldrick, From "9-11" to the "Iraq War 2003": International Law in an Age of Complexity (2004); Anna Carline and Zoe Pearson, Complexity and Queer Theory Approaches to International Law and Feminist Politics: Perspectives on Trafficking, 19 Can. J. Women \& L. (2007), 73; Joost Pauwelyn, At the Edge of Chaos? Emergence and Change in International Investment Law, 29 (2) ICSID Review (2014), 372; and Mark Chinen, Complexity Theory and the Horizontal and Vertical Dimensions of State Responsibility, 25 European JIL (2014), 703. 
the third wave of systems theory thinking known as complexity, the work outlines a model of State as the framing of the emergent patterned communications of co-evolved and co-existent law and politics systems. In contradistinction to much of the systems theory literature, law and politics are understood to be open, emergent, complex systems: the patterned communications of the systems are a consequence of the actions of constituent agents; their interactions with each other; and interactions with other actors and systems in the external environment. The argument is that we should understand the emergence of new States in terms of the emergence of complex systems of law and politics at the domestic level through the cognitive frame of the complex international law system-and that this model can provide the "scaffold" around which we can build our model of the international law on statehood. ${ }^{6}$

5. The work begins by briefly outlining the central disagreements in the academic literature on the international law on statehood, concluding that the differences reflect a problem familiar to scientific enquiry, i.e. the function (if any) of a third party observer and the cognitive frame through which the issue is addressed. The article also observes the influence of the metaphorical framing of State as Person, which underpins the importance of effectivite and the rejection of the possibility of relativism in the international law status of States. There is nothing intrinsically wrong in relying on metaphor to develop and defend doctrinal positions; the trick, as Vaughan Lowe observes, "is finding the right metaphor". ${ }^{7}$

6. The argument here is that we should think about the emergence of new States in terms of the emergence of new law and politics systems — and that the insights developed in the natural sciences to explain the emergence of complex systems can help us to be clear about the ways in which international lawyers can understand the emergence of new States. After explaining the ideas of complexity theory and the complex adaptive system, the work develops and defends a concept of State as the joining of the (complex) law and politics systems under a constitution. The claim is that this model of State can help us to understand the ways in which new States emerge by telling us what we should be looking for (patterns of law and politics), and helping us make sense of what we are looking at (the exercise of independent political power through law). The analysis also makes clear the importance of acknowledging the cognitive frame through which the issue will be

6 Cf. Prosper Weil, Towards Relative Normativity in International Law?, 77 American JIL (1983), 413 ("A system builder by vocation, the jurist cannot dispense with a minimum of conceptual scaffolding").

7 Vaughan Lowe, International Law (2007), 50 
addressed-the question of statehood is a question for international lawyers. The work considers the implications of the argument for the international law on statehood and recognition, and concludes by reflecting more generally on the difficulties of developing a coherent understanding of the law in this area.

\section{The complex and uncertain international law on statehood}

7. There is general acceptance that the international law on statehood is both "complex and uncertain", ${ }^{8}$ with scholars divided, in Jean d'Aspremont's terms, between "facticists" and "legalists", and "objectivists" and "subjectivists". 9 The first division is between jurists who claim that the State exists as a social fact before its capture by international law, and those who contend that the State is a creation of international law. The second concerns the question as to whether statehood can be objectively determined, or whether it is a consequence of the subjective determination of a third party. The dispute is played out in the debate over recognition. Two schools of thought can be observed. For adherents of the declaratory position, the State exists as a subject of international law as soon as it exists as a fact, independent of recognition (the "objectivist" approach). By way of contrast, the constitutive account holds that the legal status of State is constructed by way of recognition by already existing States ("subjectivist").

8. Whilst d'Aspremont is clear that the debates between the facticists and legalists and objectivists and subjectivists take place at different levels and in very different terms, it is possible to develop a typology of approaches to statehood by reference to the two schisms. (Think in terms of a 2 × 2 square with "objectivists" and "subjectivists" up the side, and "facticists" and "legalists" along the bottom, giving 4 possible combinations.) For the objectivist/facticist, an emergent entity meeting the classic criteria of effectiveness (effectivite) is a state. The argument is seen, for example, in the work of Stefan Talmon, who concludes that statehood is constituted by the factual exercise of public authority over a population and territory. ${ }^{10}$ For the

8 Robert L. Howse and Ruti Teitel, Humanity Bounded and Unbounded: The Regulation of External Self-Determination under International Law, 7(2) Law \& Ethics of Human Rights (2013), 51, 52.

9 Jean d'Aspremont, The International Law of Statehood: Craftsmanship for the Elucidation and Regulation of Births and Deaths in the International Society, 29 Connecticut JIL (2014), 201, 205-6.

10 Stefan Talmon, The Constitutive Versus The Declaratory Theory of Recognition: Tertium Non Datur?, 75 British YIL (2004), 101, 117-8. In 
objectivist/legalist, statehood is an objective legal fact. ${ }^{11}$ The argument is that statehood can be objectively determined in accordance with certain rules of general or customary international law_—often understood to be reflected in the text of the Montevideo Convention on the Rights and Duties of States, ${ }^{12}$ or a modified version of the "Montevideo formula". ${ }^{13}$ The subjectivist/legalist approach differs from the objectivist/legalist approach in that, whilst it regards State as a legal category, the position does not conclude that it is possible to objectively determine which entities will be accepted as states. This is seen in John Dugard's argument that admission to the United Nations resolves any legal controversy over the status of an emergent entity. ${ }^{14}$ Whilst

relation to the non-recognized state-like entities (Southern Rhodesia, the Turkish Republic of Northern Cyprus and the South African Bantustans), Talmon concludes that as these met the criteria for statehood, they should be regarded as "states", and that the majority of international lawyers would agree with this position (although this claim does not seem to be justified by an examination of the literature). Collective non-recognition is understood as a sanction imposed in response to some illegality in the formation or functioning of the entity which is opposable to the new state, with the objective being "to induce the State to dissolve itself and to return to the status quo ante": ibid., 181.

11 James Crawford, The Creation Of States In International Law, $2^{\text {nd }}$ edition (2006), 5. (A State is not "a fact in the sense that a chair is a fact; [it is] a legal status attaching to a certain set of affairs by virtue of certain rules or practices".)

12 Article 1, Montevideo Convention on the Rights and Duties of States, Adopted 26 December 1933. Reprinted (1934), 28 (Supplement) American JIL 75. "State", as a legal person in international law, should possess the following qualifications: (a) permanent population; (b) defined territory; (c) government; (d) and the capacity to enter into relations with other states.

13 The collective non-recognition of state-like entities (the Turkish Republic of Northern Cyprus, following an unlawful military intervention, and Southern Rhodesia, as a consequence of a denial of the right of peoples to selfdetermination) is explained in terms of a change in the practice of states that results in a modification of international law doctrine on statehood. Cf. Accordance with International Law of the Unilateral Declaration of Independence in Respect of Kosovo, Advisory Opinion, ICJ Rep. 2010, 403, para.81 ("the illegality attached to the declarations of independence by Southern Rhodesia, northern Cyprus, and Republika Srpska] stemmed [...] from the fact that they were, or would have been, connected with the unlawful use of force or other egregious violations of norms of general international law, in particular those of a peremptory character (jus cogens)").

John Dugard, Recognition and the United Nations (1987), 80. 
admission to the United Nations is a law-governed process, it is not possible to say in advance which entities will be admitted to membership. Finally, the subjectivist/facticist argument can be expressed in terms of the characterization of the pure (or extreme) constitutive position on recognition, which holds that the legal status of State is constructed by way of recognition by already existing states, ${ }^{15}$ and that states have absolute discretion in deciding which entities are to be recognized, without reference to rules of international law. ${ }^{16}$

9. The categorizations depend on two factors: (1) the function, if any, of a third party; and (2) the cognitive frame through which the issue is addressed. For the objectivist/facticist, statehood is a fact of the world: there is no need for a third party to confirm the existence of a new state, and no particular requirement for expert or specialized knowledge. For the objectivist/legalist, statehood is also a fact of the world, but it is a fact that must be established objectively in accordance with rules of international law- and therefore must be addressed through the cognitive frame of international law (i.e. in accordance with the mindset of the international lawyer). Both the subjectivist/legalist and subjectivist/facticist approaches accord primacy to the function of the third party observer: for the subjectivist/facticist, any entity can be "made" a State by way of recognition of already existing states; the same argument can be made in relation to the approach of the subjectivist/legalist- with the proviso that the issue must be addressed through the cognitive frame of international law, i.e. in accordance with rules established under international law.

10. The scheme demonstrates the way in which the different

15 L. Oppenheim, International Law: A Treatise, Vol. I. Peace [1st ed.] (1905), 109 ("“a] State is and becomes an international person through recognition only and exclusively"); also Hersch Lauterpacht, Recognition in International Law (1947), 41 ("the constitutive act creative of statehood is an act of unfettered political will divorced from binding considerations of legal principle"). See also Christian Hillgruber, The Admission of New States to the International Community, 9 European JIL (1998), 491, 492.

16 Crawford expresses the argument in the following way: the subjectively in the notion of the State inherent in the constitutive account effectively destroys the concept it seeks to define, as there are no constraints on the types of entities which can be recognized as states: Crawford, above n.11, 438. In the context of Palestine, however, Crawford argues that where the establishment of statehood is prevented by the serious default of another party to the prejudice of the self-determination unit, "circumstances can be imagined where the international community would be entitled to treat a new State as existing on a given territory, notwithstanding the facts" (emphasis added). Ibid., 448. 
approaches in the mainstream literature on the international law on statehood rely (if only implicitly) on divergent conceptual modes of enquiry that can result in different conclusions as the statehood claims of emergent entities. ${ }^{17}$ Often these models are expressed as metaphor, ${ }^{18}$ and often those metaphors depend on developments in the natural sciences. ${ }^{19}$ It is then noteworthy that the explanatory accounts of the international law on statehood often rely on one particular metaphor: the idea of State as Person, which re-emerged in the $19^{\text {th }}$ century after the publication Charles Darwin's On the Origin of Species By Means of Natural Selection in 1859.20 The figure of speech is common in the international law discipline; ${ }^{21}$ in the literature on statehood, it is said to be

17 See, on this point, Annelise Riles, Models and Documents: Artefacts of International Legal Knowledge, 48 ICLQ (1999), 805, 808.

18 Max Black, More about Metaphor, 31 Dialectica (1977), 431. The function of metaphor is to make difficult concepts easier to understand by comparing one concept to another in a different domain that we are more familiar with. Contemporary metaphor theory tells us that the cognitive frames that help us to make sense of the natural and social worlds are, in large part, determined by metaphor-and that these are not arbitrary. George Lakoff, The Contemporary Theory of Metaphor, in: Anthony Ortony (ed.), Metaphor and Thought, $2^{\text {nd }}$ edition (1993), 202, 243.

19 J. Robert Oppenheimer, Science and the Common Understanding (1954).

20 The idea of State as Person can be traced back to Aesop's fable of the Belly and the Members, through Christian ideas of human society, to the medieval conceptualization of the King's Two Bodies. The trope fell out of favour following the publication of Isaac Newton's Philosophix Naturalis Principia Mathematica in 1687, when the dominant analogy became that of the machine (and we still refer to the machinery of government). The body politic metaphor re-emerged at the end of the $19^{\text {th }}$ century, when the organism replaced the machine as the dominant metaphor for conceptualizing the social world and technological developments (telegraph and railways) and new discoveries (including the mammalian nervous system) led to new ways of thinking about a more interconnected social world. See Martin Landau, On The Use Of Metaphor In Political Analysis', 28 Social Research (1961), 331; also A. D. Harvey, The Body Politic: Anatomy of a Metaphor, 275 (1603) Contemporary Review (1999), 85.

21 Grotius, for example, defines the State as "a perfect body of free men": The rights of war and peace, including the Law of Nature and of Nations [1625] (1901), Bk. I. Ch. I. \XIV; Vattel refers to the State as a "moral person, who possesses an understanding and a will peculiar to herself, and is susceptible of obligations and rights"; Emer de Vattel, The Law of Nations, Or, Principles of the Law of Nature, Applied to the Conduct and Affairs of Nations and Sovereigns [1758] (2008), Preliminaries, \2. For a modern invocation, see Antônio Augusto Cançado Trindade, International Law for Humankind: 
"omnipresent".22 State as Person explains the references to the birth of new states, ${ }^{23}$ given that birth is the standard metaphor for making or creating physical objects or abstract entities, ${ }^{24}$ notwithstanding the self-evident deficiencies in the anthropomorphic analogy in this context. ${ }^{25}$ Reference to the birth of new states leads inevitably to an application of the law of the excluded middle (tertium non datur): just like natural persons, states are born, ${ }^{26}$

Towards a New Jus Gentium, 2 $2^{\text {nd }}$ edition (2013), 167.

Jean D'Aspremont, above n.9, 212.

George Lakoff and Mark Johnson, Metaphors We Live By (1980), 117.

24 We see reference to the birth of states in the literature: see, for example, Phillip Jessup, The Birth of Nations (1974). The International Court of Justice has referred directly to the "birth of so many new states": Legal Consequences for states of the Continued Presence of South Africa in Namibia (South West Africa) notwithstanding Security Council Resolution 276 (1970), Advisory Opinion, ICJ Rep. 1971, 16, para.52. The Court also referred to the "birth of the United Nations", ibid., para.55.

25 Edwin Dewitt Dickinson, The Analogy between Natural Persons and International Persons in the Law of Nations, 26 Yale LJ (1917), 564, 588 (states have a population and a territory; they are immortal - none of this can be said of natural persons: "physical entities created by the natural processes of reproduction").

26 Stefan Talmon, above n.10, 125 ("[m]uch like the birth of a child, the creation of a State is predominantly a question of fact, not of law"). Elsewhere, Talmon writes that states, "like natural persons[,] attain legal personality at birth; that is, they are "born" subjects of international law"; ibid., 106. The State as Person metaphor has also been relied on by scholars who have a different understanding of the way in which statehood is established. Anne Peters refers to the idea that "wrongful birth" precludes statehood to explain a modification to the "Montevideo formula" by reference to the emergence of jus cogens norms; Anne Peters, "Statehood after 1989: "Effectivités" between Legality and Virtuality", 3 Proceedings of the European Society of International Law (2010) [SSRN], 6. Consider also the choice of words of the constitutive scholar Christian Hillgruber in explaining the lack of statehood of Southern Rhodesia: "In the eyes of the international community, the State founded by Ian Smith's regime suffered from an incurable 'congenital defect' $[\ldots]$ that made it illegal under international law". Christian Hillgruber, above n.15, 506. Finally, in relation to the idea that admission to the United Nations confirms statehood, note the words of Palestinian President Mahmud Abbas: in according Palestine the status of non-member observer state, the United Nations General Assembly had thus issued a "birth certificate to the Palestinian state"; quoted Jure Vidmar, Palestine and the Conceptual Problem of Implicit Statehood, 12 
and it is contrary to common sense to conclude that a legal person can exist, or not, depending on the conclusions of an observing party- the principal argument against the constitutive account of recognition. ${ }^{27}$ Rather than begin with the image of Leviathan, ${ }^{28}$ and an explanation grounded in nineteenth century biological thought, the argument here is that we international lawyers should look to the insights from systems theory, specifically complexity theory - a way of thinking about the natural and social world that emerged towards the later end of the twentieth century-to model the emergence of new states.

\section{Complexity theory}

11. The argument from systems theory (specifically communications systems theory) is that we should think in terms of functional communications systems (the law system, the political system, the economics system, etc.) which have their own ways of understanding the world that results in each developing a distinctive rationale for dealing with problems. "Complex adaptive systems theory", or "complexity theory", or simply "complexity" is one variant of systems theory. Complexity emerged as a body of scientific thinking that further challenged the Newtonian paradigm of a Clockwork Universe that could be taken apart and subjected to analysis. Complex systems are often contrasted with complicated systems, like a car, which can be understood by examining the component parts and seeing how they work together. The prior assumption was that all systems were complicated systems, i.e. they were the "sum of their parts", and that the future shape and form of any system could, in principle, be predicted-think of the mechanical models of the Solar Systems. ${ }^{29}$ The insight from scientists working on the weather and those looking at cells, the brain, ecosystems, etc. was that certain (chaotic

Chinese JIL (2013), 19.

27 Stefan Talmon, above n.10, 102 (" $[\mathrm{t}]$ he most compelling argument against the constitutive theory is that it leads to relativity of the "State" as subject of international law"). The declaratory position has come to dominate the mainstream international law literature, largely as a reaction against the relativism permitted by the constitutive account. James Crawford argues that the relativism of the constitutive position is "a violation of common sense", and, if it cannot be explained, "the position itself must be flawed". James Crawford, above n.11, 21-22.

28 Thomas Hobbes, Leviathan (1651).

29 After losing money in the South Sea Bubble in the early part of the eighteenth century, Sir Isaac Newton is said to have commented: "I can calculate the motions of heavenly bodies, but not the madness of people." 
and complex) systems could not be understood in a reductionist way. ${ }^{30}$ These systems were observed to be "greater than the sum of their parts". It is not possible, for example, to understand an ecosystem (the patterned behaviours of organisms within a particular space) simply by examining the constituent elements. ${ }^{31}$ In a complex system, patterns are the result of the actions and interactions of constituent agents and their interactions with the environment "outside" of the system that produces complex behaviours at the edge of chaos: the place between entropy (where the order of the system decreases over time) and chaos (too much activity).

12. Complex systems are distinguished from other types of systems in part by the fact they are self-organizing. The capacity for self-organization allows complex systems to change their internal structures in response to developments within the system and events in the external environment. The structure of the system (the positions, actions and reactions of agents) occurs spontaneously as the result of the interactions of the parts of the system as they react to the flow of information through the system. The capacity for self-organization is the property of a complex system that enables it to process and make sense of information in order to develop or change in response to changes in the environment. The idea of "emergence" is used to describe the patterns, structures and properties seen at the level of the system that cannot be deduced from examining the individual component elements alone. ${ }^{32}$ The structure of a complex system is not then the result of some a priori design or the decisions of a "central controller" 33 or "guiding hand"; it is a consequence of the actions and interactions of agents as they react to the flow of

30 Chaos theory observes that the elements of certain systems, the weather is the paradigmatic example, sometimes combine to produce unpredictable consequences, and that small inputs can have disproportionately large outputs. This idea is referred to as non-linearity, or (metaphorically) the 'butterfly ffect', after the title of a paper by Edward Lorenz, whereby the flapping of the wings of a butterfly in Brazil is said to cause a tornado in Texas. See, generally, James Gleik, Chaos: The Amazing Science of the Unpredictable (1997).

31 John H. Miller and Scott E. Page, Complex Adaptive Systems: An Introduction to Computational Models of Social Life (2007), 10. ("The ability to collect and pin to a board all of the insects that live in the garden does little to lend insight into the ecosystem contained therein".)

32 Jeffrey Goldstein, Emergence as a Construct: History and Issues, 1 Emergence (1999), 49, 58.

33 Cliff Hooker, Introduction to Philosophy of Complex Systems, in: Cliff Hooker (ed.), Philosophy of Complex Systems (2011), 3, 42. 
information through the system-and the interactions between the system and the external environment.

13. Through the actions and reactions of component agents, complex systems evolve over time-often quickly and dramatically, and often as the result of seemingly minor events in the external environment. ${ }^{34}$ The future shape and structure of a complex system cannot therefore be predicted. That is not to say that the evolution of a complex system is unpredictable. Three issues limit their future shape and form: their history, environment, and the presence of attractors. These establish the system's "state space": the range of possible futures open to the system. The concept of hierarchy also has a particular meaning when applied to complex systems. However we think about the relationships between complex systems (as agents in higher systems, or cross-cutting systems with tangled interactions, etc.), 35 a complex system is, by definition, functionally autonomous: where there is an external controlling power, a system cannot be understood as a complex system.

14. When agents in a complex system act they do so in a thinking way, i.e. they are not simply reacting to information received. Where the interactions of actors create new patterns in response to new information, the system as a whole is said to have learnt and adapted and evolved. Learning is not possible without some form of memory that contains information that is important to the existence of the system. In order to adapt, evolve and change- and not simply mirror the environment - the system must have a memory, and therefore a history. ${ }^{36}$ The bistory of the system helps to determine its structure, representing the remembering by the system of the processes of self-organization that resulted in its extant structures and processes. That history constrains the possible futures of the system: path dependency means that the future of a complex system depends, in part, on its past.

15. The objective of complexity theory is to explain the emergence and functioning of complex systems. The insights from complexity theory thinking have been applied in a wide variety of contexts, in both the natural and the social sciences-to economic systems, the World Wide Web, and to

34 Where significant changes in the structure of the system occur in response to events in the external environment we can refer to a point of bifurcation: Göktug Morçöl, What Is Complexity Science? Postmodernist or Postpositivist?, 3 Emergence (2001), 104, 113.

35 W. Brian Arthur, et al., Introduction, in W. Brian Arthur, et al. (eds.), The Economy as an Evolving Complex System II (1997), 1, 4.

36 Paul Cilliers, Complexity and Postmodernism: Understanding Complex Systems (1998), 91-92. 
human societies, whether organized at the local or global level. There is, though, no paradigmatic science or philosophy of complexity, nor any agreed definition of the complex adaptive system, and no consensus as to the ways in which complex systems behave. At their most basic, complex systems can be understood as networks of interacting agents that are capable of adapting in response to the actions of others. ${ }^{37}$ They have the following characteristics: (1) complex systems are self-organizing, emergent systems; (2) they produce and use information from their internal and external environments; and (3) they adapt their functioning through learning processes. ${ }^{38}$ The key point is that agents are, to some degree, autonomous, whilst interacting directly and indirectly with other actors and agents, making the overall behaviour of the system difficult to predict. The argument here is that law and politics are complex systems and that this has important implications for how we model the emergence of new states.

\section{The "state" as the joining of law and politics systems}

16. From the time of Hugo Grotius, the idea of the State has been understood by international lawyers as an independent political community, organized in a particular territory, under a coercive system of government that operates through law, and which represents that community with similar communities. Statehood is understood in terms of the internal and external expressions of sovereign authority. Within the state, sovereignty is the exclusive right to exercise coercive political power. Outside of the state, it expresses the idea of membership in the international community. The criteria for statehood are: population; territory; independent government; and a legal system that is not subject to the authority of the legal system of another state. This understanding is generally reflected in the literature and forms the basis of the "Montevideo formula". Whilst we might conceptualize the idea of State in any number of ways_— through observing actors or actions, for example_- the argument here is that we should model State in terms of the co-evolution and coexistence of systems of law and politics. This understanding is captured by

37 Francis Heylighen, Paul Cilliers and Carlos Gershenson, Philosophy and Complexity, in Jan Bogg and Robert Geyer (eds.) Complexity, Science and Society (2007), 117, 125.

38 Melanie Mitchell, Complexity: A Guided Tour (2009), 12-13. For similar definitions, see M. Mitchell Waldrop, Complexity: The Emerging Science at the Edge of Order and Chaos (1992), 11; Neil Johnson, Simply Complexity: A Clear Guide to Complexity Theory (2009), 13-16; and Paul Cilliers, What Can We Learn From A Theory Of Complexity?, 2 Emergence (2000), 23, 24. 
the references to the "sovereign and independent" state_— from Vattel's Le droit des gens, ${ }^{39}$ to the United Nations Declaration on Friendly Relations. ${ }^{40}$ It reflects two ideas: (1) that there is a functionally independent political community, with a coercive system of government; and (2) that the government operates through law, and that the law system is also functionally independent. Expressed in the language of systems theory: State can be represented as the coupling of the law and politics systems under a constitution. ${ }^{41}$

17. The distinctive claim here is that law and politics are complex systems - and that this insight has important implications for how we understand the emergence of new states. Take the example of the law system. We can observe that certain law actors and institutions (legislatures, judges, etc.) produce law norm communications directed at the subjects of the law system, and that in doing so they follow rules, but act with some autonomy. In the terminology of complexity theory, these law actors and institutions are agents: the basic units of any complex system. We can further observe that certain law agents are in an on-going relationship with other law agents, i.e. they react directly to the law norm communications of other agents (courts and parliaments, for example). We can understand this on-going relationship in terms of a network (in the ordinary meaning of the term). The patterns of communications promulgated by law agents in a networked relationship can be framed as the "law system": the emergent, undirected, pattern of law normative communications adopted by law authorities (legislatures, administrative bodies, courts, and others) and applied to subjects. This ("law") system can be mapped or modelled as a pattern of law normative communications between law authorities and subjects: "It is unlawful for X to kill Y", "It is unlawful for A to break their contractual arrangement with B", etc., etc. The pattern is not the result of the decisions of any central controller or guiding hand-neither the legislature nor Supreme Court is able to control the shape of the entire law system-it emerges through the actions and interactions of a network of law agents: legislatures, courts and tribunals, etc.

18. In order to act and react, law actors and institutions must be able to

39 Emer de Vattel, above n.21, Bk. I. Ch. I. $₫ 4$.

40 GA Res 2625 (XXV), Declaration on Principles of International Law Concerning Friendly Relations, 24 October 1970.

41 For a similar argument (albeit developed within the closed systems theory of autopoiesis), see Niklas Luhmann, Theory of Society, Volume 2, translated by Rhodes Barrett (2013), 73; also Chris Thornhill, A Sociology of Constitutions: Constitutions and State Legitimacy in Historical-Sociological Perspective (2011). 
process information in order to decide what to do next. Where the interactions of these agents create new patterns in response to new information, the law system can be said to have learnt and adapted and evolved. Learning is not possible without some form of memory, which is stored and dispersed throughout the system. ${ }^{42}$ The capacity for selforganization allows a complex system to change its internal structures in response to developments within the system and to events in the external environment. As it evolves, the law system builds on its collective memory, changing its structure and form as agents react to the flow of information through the system-although always within the boundaries of what is understood to be possible (the system's state space). This is seen most clearly in the common law, ${ }^{43}$ and the related judicial principle of stare decisis. ${ }^{44}$ The memory of the law system (the history of previous actions and interactions) is dispersed throughout: in statutes, court judgments, practitioner manuals and academic textbooks. System memory provides feedback to law actors and institutions as to how they should behave (higher courts bind lower courts, legal rules are interpreted logically and in accordance with precedent, etc.), 45 but without determining future behaviour in all circumstances-constitutions are revised or replaced, ${ }^{46}$ legislatures adopt radical law reform, and supreme courts overturn long-established precedent. In other words, law is an emergent, complex, self-organizing system in which a network of actors capable of responding to other actors and other systems operate with no overall guiding hand, giving rise to complex collective behaviour that can be observed in patterns of law norm communications.

19. Similar points can be made about the politics system-which, let it not be forgotten, operates (legitimately) through the complex law system. The politics system can be understood as the emergent pattern of regulatory communications promulgated by political authorities (the government) to

42 Paul Cilliers, above n.36, 11.

43 Daniel M. Katz et al., Social Architecture, Judicial Peer Effects And The "Evolution" Of The Law: Toward A Positive Theory Of Judicial Social Structure, 24 Georgia State University LR (2007-2008), 977. See also J.B. Ruhl, The Fitness of Law: Using Complexity Theory to Describe the Evolution of Law and Society and Its Practical Meaning for Democracy, 49 Vanderbilt LR (1996), 1407, 1471.

44 Oona A. Hathaway, Path Dependence in the Law: The Course and Pattern of Legal Change in a Common Law System, 86 Iowa LR (2000-1), 601.

45 J.B. Ruhl, Law's Complexity, above n.3, 894-5.

46 Donald T. Hornstein, Complexity Theory, Adaptation, and Administrative Law, 54 Duke LJ (2005), 913, 932. 
subjects (the governed). There is no single guiding hand or omnipotent power, as regulations can be adopted by legislatures, executives and administrative bodies. In the words of Niall Ferguson: "Regardless of whether it is a dictatorship or a democracy, any large-scale political unit is a complex system." 47 Collectively binding decisions emerge as political actors and institutions process information, often relying on feedback loops. ${ }^{48}$ The system has its own memory, which limits the possible scope of future decisions, and its own ways of thinking. Political systems can change in unexpected ways (often quickly) — consider the democratic revolutions during the so-called "Arab Spring". ${ }^{49}$ To survive, a politics system must adapt and evolve with other systems in the world. Finally, the boundaries of political authority are not always clearly demarcated. Politics systems are open systems, interacting with other politics systems and political communications at one level can form part of the politics system at another-consider the way in which global communications are part of domestic politics on such subjects as military and humanitarian interventions, climate change, and commitments for overseas development assistance.

\section{The emergence of new states}

20. Systems theory directs us to think about the State in terms of the joining of the law and politics systems under the constitution; complexity that these are open, emergent systems that develop without any central controller or guiding hand. From the perspective of complexity theory, the emergence of new states must be understood as a two-stage process: first, we must be able to see the patterns of regulatory communications adopted by law and politics actors and institutions; second, we need to allocate meaning to those patterns

47 Niall Ferguson, Complexity and Collapse Empires on the Edge of Chaos, 89 Foreign Affairs (2010) 18, 26. For a useful introduction to complexity applied to the politics system, see Robert Geyer and Samir Rihani, Complexity and Public Policy: A New Approach to 21st Century Politics, Policy and Society (2012).

48 Complex systems rely on negative and positive feedback loops. Positive feedback is self-reinforcing, causing pressure for change in the same direction; negative feedback is stabilizing, creating pressure for the system to return to its previous position. Moreover, complex systems are non-linear: small inputs can have disproportionately large effects (the so-called butterfly effect), and an apparently stable system can change suddenly, often in unpredictable ways.

49 Seva Gunitsky, Complexity and Theories of Change in International Politics, 5 International Theory (2013), 35. 
to decide whether an emergent entity can be regarded as a "state"- and we do so (inevitably) with the mindset of an international lawyer, i.e. we are looking for law and politics systems in order to observe a state-as opposed to simply looking at patterns of communications of law and politics actors and institutions. What matters is how we frame these systems: how we separate law and politics systems from the background noise of world society (the totality of law, politics and other systems and communications that structure and give meaning to human societies) in order to make sense of the phenomenon we are observing.

21. The first thing is to separate the law and politics systems from the environment. We must enquire whether, as a fact of the world, there are patterns of regulatory directives adopted by law and politics institutions that are applied to subjects- this distinguishes claims to sovereign authority from (a) the exercise of naked power by the "bandit"; 50 and (b) non-territorial governance systems which do not coercively enforce their regulatory norms. There must be, as a social reality, law and politics actors and institutions promulgating authority directives to subjects, with those authority directives being coercively enforced. In the absence of de facto coercive power over subjects, there is no politics system (properly understood) —and no claim to statehood for emergent entities. ${ }^{51}$

22. The separation of systems of law and politics from the wider environment is no easy task. As a result of their incompressibility (complex systems cannot be simplified without losing some element that makes them complex) and open nature (agents sometimes interact directly with agents and elements outside of the system, including with other systems), any description of a complex system and its boundaries inevitably involves the making of choices by the observer "framing" the system..$^{52}$ It follows that the boundaries of a complex system are both a function of the operations of the system (there must be patterned behaviour that can be observed) and the understanding imposed by the observer when separating the system from its environment. The fact of observation is integral to the identification of complex systems, including the complex systems of law and politics. Moreover, given the need to simplify a complex system in order to describe it

50 See on this point, Hans Kelsen, General Theory of Law and State, transl. Anders Wedberg (1999), 31.

51 This work does not consider whether entities such as Poland (1939-45), Kuwait (1990-1), or Somalia (1991-) should continue to be regarded as "states" where they lack an effective political system.

52 Paul Cilliers, Complexity, Deconstruction and Relativism, 22 Theory, Culture \& Society (2005), 255, 258. 
and the open nature of complex systems, it is possible for there to be different descriptions by different observers, relative to the perspective from which the description is made-and no reason to conclude that each observer will see the same version of the system, or, in cases of disagreement, to prefer one version or vision of the system or boundary to another. The fact that complex systems cannot be modelled perfectly means that any description of a complex system will then involve the exercise of subjective judgment by the observer framing the system.

23. Once we are satisfied that (as a fact of the world) there are patterns of regulatory communications adopted by law and politics institutions and applied to subjects, we need to make sense of those patterns of communication. The establishment of statehood (when understood from the perspective of systems theory) involves the allocation of meaning to the actions of law and politics actors and institutions through the cognitive frame of international law, i.e. in accordance with the understanding of international lawyers. The point is significant. International law is the paradigmatic complex system, emerging through the actions and interactions of states and other international law actors as they react to new information and new events. The international law system evolves over time, adapting to developments within the system and the wider environment, but in ways that cannot be predicted. This is seen clearly in relation to the formation of customary international law, a "decentralized[,] bottom-up process" (in the words of Michael Wood), 53 which develops through the "actions and reaction" of states, ${ }^{54}$ without the need for any central controller or guiding hand. All states may contribute, and it is difficult for any one State to exercise a decisive influence. The emergent nature of international custom is confirmed by the fact that its content is not contained in a central registry (cf. the United Nations Treaty Collection), but dispersed throughout the system-in judgments of courts and tribunals and in the writings of publicists, including textbooks and reports by bodies such as the International Law Commission and the International Law Association. This constitutes the memory of the international law system and, like all memories, it is partial and selective (some issues are remembered, some forgotten). System memory informs the on-going practices of states, which operate in accordance with international law rules, limiting the possibilities of

53 Michael Wood, Special Rapporteur, First report on formation and evidence of customary international law, International Law Commission, Sixty-fifth session UN Doc. A/CN.4/663, 17 May 2013, para.96.

54 Krzysztof Skubiszewski, Elements of Custom and the Hague Court, 31 Zeitschrift für Auslandisches Öffentliches Recht und Völkerrecht (1971), 810,812 ("the practice of States is built of their actions and reactions"). 
future actions and reactions.

24. In the hypothetical state of nature, it might have been possible to conceptualize the emergence of new systems of law and politics (and therefore new states) in isolation from other law and politics systems. This is no longer the case. The globalization of sovereignty means that all permanently inhabited territories are subject to the claims of already existing law and politics systems. We are required then to make sense of the emergence of new systems of law and politics against the background noise of the law and politics systems of already existing territorial states. This requires that we reorient our analysis away from considerations of a "right" to territorial integrity versus a "right" to statehood to consider the conflicting claims to constitutional authority by the emergent entity (which must demonstrate that it has authority) and that of the already existing State (where the focus must be on the loss of authority).

25. The standard accounts in international law provide that statehood is established where we observe a new independent political community, organized in a particular territory, under a coercive system of government that operates through law, and which is able to represent the community with similar communities. Controversies in relation to the international status of a political entity do not normally concern the question as to whether it has a system of "law"- although this point has been come before the European Court of Human Rights in relation to the Turkish Republic of Northern Cyprus. ${ }^{55}$ The focus will then be on the nature of the politics system. The traditional approach of the international law system was to understand statehood in terms of effectiveness (effectivite): the coercive use of political power within the State and the possibilities of engaging with other sovereign political communities in the international community. ${ }^{56}$ In the language of systems theory, a new State could be observed where a government adopted binding decisions in the form of law that were coercively enforced against a population.

26. The last 50 years, has, though, seen a dilution of the importance of effectiveness, with considerations of legitimate authority now both supplementing and undermining claims to statehood: an ineffective but legitimate political community may be recognized as a State (Guinea-Bissau, Croatia, Bosnia and Herzegovina), whilst an effective but illegitimate political community may not be recognized (Southern Rhodesia, Turkish Republic of

55 Protopapa v. Turkey, App. No. 16084/90, Judgment 24 February 2009.

56 See Robert J. Oppenheim, above n.15, 112-3 (a community able to establish itself "safely and permanently" and to exclude the authority of the already existing State has a claim to statehood). 
Northern Cyprus, and Transdniestria). The international law system is not only concerned with the factual existence of coercive power, but also the justification for the exercise of that power. The politics systems of emergent entities must (now) make a claim to legitimate political authority. ${ }^{57}$ The paradigmatic examples are Sothern Rhodesia and the South African Bantustans of Transkei, Bophuthatswana, Venda, and Ciskei. Despite exercising effective control over a territory and population, these entities were not recognized as states as they were established in violation of the principle of self-determination of peoples. ${ }^{58}$ This is often explained in terms of the influence of jus cogens norms on the law of statehood: an entity will not be recognized as a State where the circumstances of its "creation" violate an international law norm of jus cogens standing, including the prohibition on systematic racial discrimination and violations of the right of peoples to selfdetermination (at least in the colonial context). ${ }^{59}$ But there is another way of understanding the non-recognition of these entities: Sothern Rhodesia and the Bantustans were not accepted as states because it could not plausibly be argued that the government represented the people of the territory. In the language of systems theory: the international community could not see a pattern of political communications promulgated by the government and accepted by the governed, even if it could see the exercise of coercive power and an effective legal regime. In other words, the international law system could not see a politics system. This is significant, as where the international community cannot see a politics system (properly understood), it cannot see a new state.

27. In relation to the State against which a claim to statehood is made, the international law doctrine and practice outlines five circumstances in which the authority (the "right to rule") of an already existing State will not be accepted. ${ }^{60}$ First, in cases of separation, where a new State is created with the

57 See, for example, EC "Guidelines on the Recognition of the New States in Eastern Europe and in the Soviet Union" 31 ILM (1992), 1486; also Badinter Arbitration Commission of the International Conference on Yugoslavia Opinion No. 10, 4 July 1992, para.4. Reprinted 4 European JIL (1993), 90. Public International Law (2011), para.10.

59 See, for example, David Raic, Statehood and the Law of Self-determination (2002), 442; also John Dugard and David Raic, The Role of Recognition in the Law and Practice of Secession, in Marcelo G. Kohen (ed.) Secession: International Law Perspectives (2006), 94, 101.

60 Readers might not agree with the list presented here, but would (hopefully) accept that there are some circumstances in which the authority (i.e. the right 
consent of the existing state. Recent examples include Montenegro and South Sudan. We can understand the emergence of these new states in terms of a revised understanding (a redrawing, if you like) of the boundaries of the law and politics systems of Serbia and Montenegro and Sudan respectively. Secondly, the authority of a State will not be recognized where the relationship between the State and the entity is a "colonial" one. ${ }^{61}$ Thirdly, a State can repudiate the bonds of authority with one part of the population by making no pretence to govern in the interests of that part of the population. This is explained in terms of the "remedial right" of secession. ${ }^{62}$ Fourthly, there are occasions, for example in the case of the Socialist Federal Republic of Yugoslavia, when the international community will conclude that the existing State has undergone a process of dissolution. In these exceptional circumstances, there are factually no law and politics systems claiming authority over subjects; there is an authority vacuum that can be filled by other systems of authority. Finally, the nature of the politics system of an existing State can result in the international community refusing to acknowledge that the exercise of power is accepted by a majority of the population: the apartheid regime in South Africa is the paradigmatic example. Whilst the nature of the regime does not affect the status of the territory as a state, it is relevant when considering any "transfer" of sovereignty authority to

to rule) of an already existing State will not be accepted in international law.

61 In a number of resolutions in the 1960s, the United Nations General Assembly made clear that a colonial power did not enjoy legitimate authority over a non-self-governing territory, unless the population expressly consented to the continuing exercise of political power by the metropolitan state. See, GA Res. 1514 (XV), adopted 14 December 1960, Declaration on the granting of independence to colonial countries and peoples; and GA Res. 1541 (XV), adopted 15 December 1960, Principles which should guide Members in determining whether or not an obligation exists to transmit the information called for under Article 73e of the Charter.

62 Where a territorially concentrated group is systematically excluded from political life, secession is a potential remedy of last resort in cases of serious human rights abuses against members of the group. The right is implied by the so-called "saving clause" in GA Res. 2625 (XXV), adopted October 24, 1970, Declaration on Principles of International Law Concerning Friendly Relations and Co-operation among States in Accordance with the Charter of the United Nations. For judicial support for the remedial right to secession, see Reference re Secession of Quebec (1998) 2 SCR 217, para.134; and Kevin Mgwanga Gunme et al v Cameroon, African Commission On Human And Peoples’ Rights, Comm. No. 266/2003, 27 May 2009, para.194. 
an emergent entity. ${ }^{63}$

28. The international law on statehood is required then to explain the ways in which the conflicting and overlapping claims to constitutional authority can be addressed and resolved. These conflicts fall into one of four categories. (1) Circumstances where neither the existing State nor the emergent entity can make a claim to authority. Where there is no evidence that the population accepts the authority of the emergent entity, the international community cannot see a new state, for the reason that it cannot see a politics system-according to its own conception of what a politics system represents. Examples include Southern Rhodesia and the South African Bantustans. This is the case even when the existing states cannot make a claim to legitimate authority - the United Kingdom as the colonial power and South Africa apartheid state. (2) Circumstances in which the emergent entity cannot make a claim to governmental authority on the grounds that it is not functionally independent, e.g. Nagorno-Karabakh and South Ossetia. ${ }^{64}$ An entity subject to the binding decisions of another politics system fails to fulfil the criterion of independence and thus does not possess a politics system (properly so-called): it is (at best) a sub-system of another system. ${ }^{65}$ In these cases, the territorial State remains the de jure sovereign, even if it fails to exercise de facto authority. (3) There will be circumstances in which an emergent entity appears to exercise de facto control and enjoy the support of the local population, but the territorial State also seems to continue to enjoy a degree of sovereign authority. Examples include Abkhazia ${ }^{66}$ and the Turkish Republic of Northern Cyprus. ${ }^{67}$ The concept of the de facto regime

63 See Christian Hillgruber, above n.15, 495.

64 In relation to South Ossetia, the Independent International Fact-Finding Mission on the Conflict in Georgia concluded was South Ossetia "not a state-like entity, but only an entity short of statehood" on the grounds that Russia's control of the political decision-making process was systematic and permanent, and South Ossetia was not effective on its own account;Independent International Fact-Finding Mission on the Conflict in Georgia (September 2009), Vol. II, 134.

65 Consider, for example, the description of the Nagorno-Karabakh Republic as "a satellite 'puppet-state' or even a de facto Armenian province"; Andriy Y Melnyk, Nagorny-Karabakh, Max Planck Encyclopedia of Public International Law (2013), para.10.

66 See references to "state-like entity" (Independent International Fact-Finding Mission, above n.64) and "stabilized de facto regime" (Angelika Nußberger, Abkhazia, Max Planck Encyclopedia of Public International Law (2013), para.27).

67 See reference to "local de facto government" in relation to Northern Cyprus: 
developed by Jochen Frowein is perhaps most useful to describe an emergent entity that controls a more or less clearly defined territory, but which is not recognized by the international community as a state. ${ }^{68}$ (4) Finally, there will be situations in which the international community acknowledges the loss of sovereign authority by the existing State and the emergence of a new entity that enjoys the support of the local population and capacity to exercise coercive governmental powers. In these circumstances, the international community will accept and recognize the emergence of a new state.

29. In evaluating whether or not a claim to statehood has been established as a matter of international law the following insights from complexity emerge. First, we must check whether, as a fact of the world, there are patterns of law and politics communications promulgated by actors and institutions and applied to subjects. Second, we must consider whether we can frame those patterns of communications as systems in their own right and not merely random communications or subsystems of other systems. Third, we must enquire whether the law and politics systems are coupled under a constitution in order to distinguish the exercise of naked power from claims to legitimate authority (politics establishes the scope of effective law norms through executive enforcement; law translates power into legitimate political action). We can then ask whether there is evidence that the population accepts the constitutional regime as an authority for them. In these circumstances, the emergent entity has a claim to authority. We can then consider the claims of the existing state. Here there is a presumption in favour of stability and the status quo, as the international law system-a system that functions to avoid violent conflict and resolve disputes ${ }^{69}$ - will not lightly accept a loss of authority by a state. We must then ask whether there is clear evidence that the existing State no longer enjoys authority in relation to the population. Where it is not evident that the State no longer enjoys sovereign authority, an emergent entity that enjoys legitimate political authority will remain in a suspended condition of statu nascendi.

\section{The "recognition" of new states}

Frank Hoffmeister, Cyprus, Max Planck Encyclopedia of Public International Law (2009), para.29.

68 See Jochen Frowein, Das De Facto-Regime im Völkerrecht (1968); and Jochen A. Frowein, De Facto Regime Max Planck Encyclopedia of Public International Law (2013).

69 See, for example, Anthony D'Amato, Groundwork for International Law, above n.1, 653 . 
30. Complexity theory provides us then with a new way of thinking about the emergence of new states in the international community in a way that helps make sense of the relevant doctrine and practice. The approach from complexity suggests a two-stage process for evaluating the statehood claims of emergent entities: (1) we must be able to observe patterns of regulatory communications between law and politics actors and institutions and subjects; and (2) we are required to allocate meaning to those patterns. Where it can be observed that functionally autonomous law and politics systems operate with the consent of the subjects of the constitutional regime-and the already existing State no longer enjoys the right to rule, we can conclude that the statehood claims of the emergent entity have been established. Where the autonomy of the law and politics systems cannot be established, or it is not clear that the regime operates with the consent of subjects, or it is not clear that the already existing State no longer enjoys the right to rule, statehood cannot be established - and de jure territory sovereignty is retained by the already existing state.

31. The question is "who decides"? Who decides when an emergent entity should remain part of the territorial state, or be accepted as a de facto regime, or recognized as a "state"? The response of the "objectivists" (to use Jean d'Aspremont's term) would be that "no one decides": statehood is either an objective fact of the world (evidenced by effectivite) or established in accordance with objective legal criteria. The analysis developed here, from the perspective of complexity, demonstrates, however, that when we conceptualize the "sovereign and independent" State in terms of the joining of the law and politics systems under a constitution, State does not exist as an objective reality: it is observed by a third party trying to make sense of the patterns of law and politics communications against the background noise of world society. Given the inherent indeterminacy in the modelling of the complex systems of law and politics, we cannot be certain that we have correctly identified emergent and autonomous systems of law and politics. In other words, once we accept that law and politics are complex systems, we must reject any argument that a State can have an objective reality, either because it exists as a fact of the world, or as an objective category that all reasonable observers would recognize, given that different actors may come to different conclusions as to the statehood claims of emergent entities, depending on the meaning they allocate to the patterns of law and politics communications that they can observe.

32. The conclusion locates the argument firmly within the subjectivist literature, which, as previously noted, can be divided between those writers who argue that statehood is constituted through the recognition of an emergent entity as a State (nothing more is required); and those whose 
position is that statehood is established by admission to the United Nations, accepting that it is not possible to say in advance which entities will be admitted to membership. The analysis from complexity takes a different approach. It rejects the contention that statehood can be constituted by recognition alone: whether taken individually or collectively through admission to the United Nations. Complexity tells us that the identification of the complex systems of law and politics for the purposes of establishing statehood requires (1) the factual reality of patterned behaviour; (2) the observation of that patterned behaviour; and (3) an evaluation of that patterned behaviour through the cognitive frame of international law. Moreover, this is not the first article to make this point (albeit in very different terms).

33. In his paper "Recognition of States in International Law", which is substantially reprinted in Recognition in International Law, ${ }^{70}$ Hersch Lauterpacht argues that whilst recognition is declaratory that an emergent entity fulfils the necessary criteria for statehood established by international law, it has constitutive effect for the commencement of international rights and duties, and in that sense is constitutive of statehood for the entity in question. Recognition is not then a question of unfettered (political) discretion, but of establishing whether the required conditions exist for the identification of statehood: independent government, effective authority, and defined territory. Given the absence of a centralized political or judicial authority, the functional responsibility to accord the status of State to political communities is undertaken by states (separately) on behalf of the international community. Lauterpacht concludes that once a State had observed the relevant conditions of statehood in an emergent entity, it is under a duty of recognition, ${ }^{71}$ and that this duty exists as a matter of law and practice - a position that finds limited support in the literature. ${ }^{72}$ This misstep, of arguing for the recognition of a duty of recognition, should not blind us, however, to his main point: that the recognition of new states involves the evaluation of facts concerning the exercise of independent governmental authority in relation to a particular territory for the purpose of establishing whether the conditions for statehood

70 Hersch Lauterpacht, Recognition in International Law (1947), Part I.

71 Hersch Lauterpacht, Recognition of States in International Law, 53 Yale LJ (1943-4) 385, 454 ("recognition, while constitutive of the international personality of the new State, is declaratory of an existing physical fact. If this fact is present, the established States fall under a duty to declare its existence and thus to bring into being the international rights and duties of the new State.”).

72 See further Patrick Capps, Lauterpacht's Method, 82 British YIL (2012), 248. 
have been met, ${ }^{73}$ and that, in this evaluation, the observing State is entitled to exercise its discretion: "This is a judicial discretion, however, aimed at ascertaining the existence of the relevant facts." 74 Chinese scholar Ti-Chiang Chen expresses a similar idea, when he concludes that the requirements for the recognition of new states are established by the reference the international law criteria for statehood-acknowledging that scholars may differ as to the precise formulation. The application of the requirements for statehood cannot, however, be separated from the factual realities: "recognition cannot be divorced from fact." 75 Through recognition "a State declares, admits, and accepts a state of facts and outwardly manifests the mental comprehension of such facts". ${ }^{76}$

34. Lauterpacht's solution to the problem of recognition was to propose the "collectivization of the process": recognition should be undertaken by the highest executive or legislative organs (not a judicial body) of a "universal international organization", with entities admitted to the organization and therefore statehood "by an appropriate majority". 77 This has now become the mainstream position in the literature on statehood. Jure Vidmar summarizes the point this way: "when an entity joins the UN, this ends any doubt pertaining to its legal status-it definitely is a state". ${ }^{78}$ There are two possible justifications for this: first, drawing on the conclusions of the International Court of Justice in the Reparation case, that the "vast majority of the members of the international community" can bring into being an entity possessing objective international personality, with that legal personality opposable to all states; ${ }^{79}$ second, that a majoritarian principle applies in the practice of recognition in the case of admission to the United Nations. ${ }^{80}$ The

73 Lauterpacht argues that premature recognition is wrong, not only because it infringes the sovereignty of the territorial state, but also because it "acknowledges as an independent State" a political entity that fails to fulfil "the essential conditions of statehood"; Hersch Lauterpacht, above n.71, 392.

74

75

76

77

78

Jure Vidmar, Democratic Statehood in International Law: The Emergence of New States in Post-Cold War Practice (2013), 38.

79 Cf. Reparation For Injuries Suffered In The Service Of The United Nations, Advisory Opinion, ICJ Rep. 1949, 174, 185.

80 Hersch Lauterpacht, above n. 70, 403 ("a majority thus constituted ought to be treated as sufficient proof that the new State [...] possesses the necessary qualifications entitling it to recognition"); also Crawford, above n. 11, 438 
first depends on according a special significance to the admission process of the United Nations. ${ }^{81}$ The second on an application of a super-majoritarian principle, with writers referring to the possibility of a State emerging as an objective reality following "widespread recognition", ${ }^{82}$ or with "quasiunanimous support". ${ }^{83}$ In both cases, the argument is that the establishment of statehood through admission to the United Nations is opposable to those states that do not already accept that the entity is a state.

35. The idea that admission to the United Nations resolves any question of the statehood claims of an emergent entity, though superficially attractive, does not work as a matter of practice, law or principle. As a matter of practice, non-states have been full members of the United Nations (Belarus SSR and Ukraine SSR). As a matter of law, it is difficult to develop a compelling argument that admission constitutes an international law status opposable to all other states - the argument seems to be that, as co-members of the United Nations, states are required to deal with each other on the basis of equality within the Organization (but that is not the same as recognizing the other as a state). The requirements for admission to the United Nations (and, according to this argument, the requirements for statehood) are 9 positive votes in the UN Security Council (out of a possible 15); the absence of a veto by one of the five permanent members; and a two-thirds majority of the members present and voting in the General Assembly. Statehood depends on an application of a law-governed procedure-but it is not possible to say in advance which entities will be accepted as states. Finally, as a matter of principle, the United Nations cannot "constitute" statehood without reference to the facts on the ground (this is a central insight from complexity theory). The admission of the fictional State of Narnia by the appropriate procedural requirements of the United Nations Charter would not mean that Narnia was a State under international law. The conclusion must be that admission to the

("There is no rule that majoritarian recognition (outside the framework of admission to the United Nations) is binding on third states." (Emphasis added)).

81 The argument of the United Nations Treaty Section of the Office of Legal Affairs is that whilst membership of an international organization is not normally determinant of statehood, membership of the United Nations is conclusive because of the onerous procedures for admission to the Organization: Treaty Section of the Office of Legal Affairs, Summary of Practice of the Secretary-General as Depositary of Multilateral Treaties, UN Doc. ST/LEG/7/Rev. 1 (1999), para.79.

82 Marc Weller, Modesty Can be a Virtue: Judicial Economy in the ICJ Kosovo Opinion?, 24 Leiden JIL (2011), 127, 130.

83 James Crawford, above n.11, 438. 
United Nations resolves problems of statehood as a practical matter (rather than as a matter of legal principle) allowing states and international law practitioners (and academics) to move forward with a shared understanding of the status of those political entities admitted to membership. Thus, for example, we are not required to deal with the status of Israel in legal disputes, notwithstanding the fact that it remains unrecognized by over 30 co-members of the United Nations.

36. Pragmatism is important here. In our analysis of the complexities of the world, there must be certain issues on which we international lawyers are agreed in order to engage in a meaningful discussion. There must, for example, be some relevance in the fact that Somaliland has not been recognized by any state, that the international community is divided in the status of Kosovo and Palestine, and that South Sudan has been admitted to the United Nations. The non-recognition of an emergent entity suggests (for whatever reason) that the international community does not regard a political community as a state. It would, then, be difficult to conclude that Moldavian Republic of Transdniestria or Nagorno-Karabakh are states given the absence of a single act of recognition by already existing states. ${ }^{84}$ The same point can be made in relation to Somaliland, notwithstanding that it is generally regarded as fulfilling the classic criteria of statehood. ${ }^{85}$ The conclusion that Transdniestria, Nagorno-Karabakh and Somaliland are not states is not a function of non-recognition; it simply reflects a pragmatic reading of the practice of states, i.e. that it is difficult to conclude that an entity is a State where it is not recognized by any state. We can refer to this as the "mainstream" international law position, which will be reflected in the practice of states and in the academic writings on the subject. This rough consensus can, though, move to dissensus and a revised consensus, and it can do so rapidly.

37. The analysis from complexity leads inevitably to a defence of the

84 James Crawford, above n.11, 93. ("At least when the recognizing government is not acting in a merely opportunistic way, recognition is important evidence of legal status.”) Jure Vidmar draws a useful distinction between universal and widespread recognition: universal recognition confirms the emergence of a new state; widespread recognition "leads at least to ambiguity regarding the legal status of an entity": Jure Vidmar, Explaining The Legal Effects Of Recognition, 61 ICLQ (2012), 361, 387.

85 Crawford, above n.11, 417 (" $[\mathrm{t}]$ he notion of a de facto regime has been pressed to its ultimate-and Somaliland is not yet a state"); cf. Jan Amilcar Schmidt, Somalia, Conflict, Max Planck Encyclopedia of Public International Law (2013), para.24 (Somaliland fulfils the criteria of statehood elaborated in the "Montevideo formula"). 
constitutive position and the associated possibility of the "grotesque spectacle" (in Hersch Lauterpacht's terms) of an emergent entity being a State in relation to some states, but not others. Hans Kelsen was famously phlegmatic about this: "[s]ince we have to acknowledge the relativity of time and space[,] relativity of legal existence is no longer paradoxical". ${ }^{86}$ Kelsen's position was attacked by Lauterpacht, who concluded that the problem could not be "explained away amidst some complacency by questionable analogies to $[\ldots]$ philosophical relativism". ${ }^{87}$ The argument from complexity provides a better way of understanding why relativism is inevitable in the determination of the international status of emergent entities - and why it is not necessarily problematic. In the observation of emergent regimes claiming the right to rule, the requirement is to apply the generally accepted international law criterion for statehood to the observed patterns of regulatory communications. The analysis here showed that in the evaluation of the status claims of emergent entities there may be legitimate differences of opinion, depending on the cognitive understanding of the process of observation (i.e. the legal "test" being applied) and the patterns of behaviours being observed (the "facts" on the ground). Disagreement in relation, for example, to the status claims of Kosovo and Palestine does not concern the question as to whether the respective entity is a State or not (the entity is, after all, what it is); disagreement simply reflects a lack of agreement between observers as to whether the correct international law test for the establishment of statehood has been applied and/or a lack of agreement as to the factual conclusions of the observer evaluating the statehood claims of the emergent entity.

86 Hans Kelsen, Recognition in International Law: Theoretical Observations, 35 American JIL (1941), 605, 609. The allusion is to discoveries in the so-called new science in the early part of the twentieth century, specifically the publication of Albert Einstein's Relativity: The Special and General Theory (1916). Scientific developments in the twentieth century have had limited influence on the metaphorical conceptualization of the social world, including within legal academia, possibly for the reason that the quantum world is beyond our everyday experience (from where we get out metaphors). The influence of the new science has mainly been by way of misapplication: we can never really know anything (Heisenberg's Uncertainty Principle); everything is relative (Einstein's Theory of Relativity); and nothing really exists until it is observed (Schrödinger's Cat). Notable exceptions to reliance on ideas and concepts from the new science include Anthony D'Amato, Counterintuitive Consequences of "Plain Meaning", 33 Arizona LR (1991), 529; and Lawrence Tribe, The Curvature of Constitutional Space: What Lawyers can Learn from Modern Physics, 103 Harvard LR (1989), 1.

87 Hersch Lauterpacht, above n.70, 78. 
Relativism describes the position and conclusions of the observer-not the status of the entity.

\section{Conclusion}

38. This article began by outlining an understanding of State in terms of the coupling of the law and politics systems under a constitution. Whilst expressed in terms of systems theory, this reflects the general understanding of State held by international law scholars since the time of Grotius and the emergence of the idea of sovereign authority. The distinctive claim here is that law and politics are complex emergent systems. Complexity theory tells us that the identification of emergent systems requires both the fact of patterned behaviour reflecting the actions, reactions and interactions of actors and institutions and the observation of that patterned behaviour by a third party observer. Only then does it become meaningful to talk about a "system" that can be separated from the wider environment. The nature of complex systems means however that it can be difficult to be absolutely certain that we can really "see" autonomous systems of law and politics or identify an objective position from which the issue can be addressed: different observers can come to different conclusions as to whether the criteria for statehood have been established.

39. The approach from complexity led to the following insights. First, we should acknowledge that we are being asked to answer a particular question, i.e. we are asked to identify new "states". Second, that we will inevitably examine the issue through the cognitive frame of international law, meaning that we are required address the problem with the mindset of an international lawyer (even if we regard states as facts of the world). Third, given that the international law system will be faced with the problem of the identification of new states in different circumstances over time and that different international law actors and institutions will attempt to "resolve" this problem (both as a matter of international law practice and doctrine), an emergent international law on statehood will develop as one part of general or customary international law to help us frame the question. In other words, the international law system will (some explicitly, often implicitly) develop a legal test for statehood that can be applied to new factual situations. There can be, however, differences of opinion between different international law actors and institutions as the relevant test to be applied—as well as to the relevant facts on the ground.

40. In the identification of new states, we can then outline the following conclusions drawing on our analysis from complexity.

41. First, there must be, as a social reality, law and politics actors and 
institutions promulgating authority directives to subjects. We must be able to see coevolved and coexistent systems of law and politics coupled under a constitution before we can see a state. Consider, for example, the conclusion of the Badinter Committee that the Federal Republic of Yugoslavia emerged on 27 April 1992, "because that was the date on which Montenegro and Serbia adopted the Constitution of the new entry and because the relevant international agencies then began to refer to 'the former Socialist Federal Republic of Yugoslavia". ${ }^{88}$ The Federal Republic of Yugoslavia was neither an objective fact, nor an artefact, constructed through recognition: its independent existence as a State was accepted at the point at which the international community could see the law and politics systems of a new State coupled under a constitution.

42. Second, the evaluation of the statehood claims of emergent entities must be undertaken through the cognitive frame of international law. In the traditional language of the international lawyer, the establishment of new states requires the identification of a new independent political community, organized in a particular territory, under a coercive system of government that operates through law, and which is able to represent the community with similar communities. In the language of systems theory, we are looking for new systems of law and politics joined under a constitution. Where there is more than one observer, there is no reason to conclude that each will frame the patterned communications of law and politics in the same way, given the inherent indeterminacy in the modelling of complex systems. Once we recognize that law and politics are complex systems, we must reject any argument that a State can have an objective reality: different actors may come to different conclusions. Complexity theory makes clear that there cannot be a single authoritative position from the which the question of statehood can be addressed —allowing for a plurality of perspectives and opinions and locating the analysis generally in line with the modified constitutive position outlined by Hersch Lauterpacht, i.e. that recognition involves the judicial-type process of applying law to facts-but with the acceptance of subjectivity and indeterminacy in both our understanding of the factual situation and the legal test to be applied.

43. Third, it is impossible to avoid disagreements as to whether this or that entity is, or is not, a state. This is not a consequence of the relativity of state, but of the fact that different observers can come to different conclusions as to whether we can frame observed patterns of communications as a "state". Moreover, the multiplication of complexity that follows the recognition that

88 Badinter Committee Opinion No. 11 (1993) 32 ILM 1587, para.7. 
the observation of the complex systems of law and politics is undertaken through the cognitive frame of the complex international law system means that we can never be confident that we have found the "right" answer. In these conditions of uncertainty the only possibility is a turn to pragmatism in the case of disputed statehood claims, allowing us, for example, to accept that Palestine can be a party to the International Criminal Court without being a member of the United Nations, without needing to resolve the Palestinian Status Question.

44. Fourth, the model developed here to explain the emergence of new states through the cognitive frame of international law highlights the importance of sensitivity to changes in the ways in which the international law system conceptualizes the emergence of new states. This can be seen in the evolution of the thinking of the international law system about the nature of the domestic politics systems at the moment of the emergence of new states, in particular its refusal to regard communications between those with power and those subject to that power as a politics system, properly so called, in the absence of evidence that the relevant population accepts the exercise of governmental authority - the case of Southern Rhodesia and its Unilateral Declaration of Independence in 1965 is the best example here.

45. Finally, complexity theory tells us that our model of the State as the joining of complex systems will always be incomplete, contingent and contestable, relieving the international lawyer of the sense that there is a definitive (yet to be identified) "test" that will be accepted by all international lawyers and which will give us the "right" answer in all circumstances. It follows that we international lawyers will inevitably continue to engage in ontological and epistemological contestations over the concept of state, and, try as we might to develop more complicated formulations, the international law on statehood is likely to remain both complex and uncertain. 